\title{
Spectrum of adverse cutaneous eruptions to nevirapine - a cross sectional study
}

\author{
Leelavathy Budamakuntla*, Prabhakar Basappa, DM Basavarajaiah, N Vidyashankar, C Madhura, N Shilpa, P Namitha, \\ C Lalitha
}

From First International Science Symposium on HIV and Infectious Diseases (HIV SCIENCE 2012)

Chennai, India. 20-22 January 2012

\section{Background}

HIV infection increases the risk of adverse drug eruptions. The reason for this is unclear; the mechanism probably involves drug specific cytotoxic lymphocytes. The aim of the study was to observe the spectrum of adverse cutaneous eruptions to nevirapine.

\section{Methods}

PLHIV initiated on nevirapine based ART regimens between 2010 and 2011, were included in the cross sectional study. These hospitalized patients were followed up for the sequence of events. A detailed concomitant drug history was taken to rule out other impending drugs which can cause similar drug reactions.

\section{Results}

In this analysis, $80 \%$ were females, $70 \%$ heterosexuals, $20 \%$ homosexuals and $10 \%$ intravenous drug users. Average age of patients was $31.70 \pm 9.89$ years. The spectrum of drug eruptions ranged from erythematous maculopapular generalized rash in $20 \%$ of patients to grade four SJS \& TEN in $80 \%$. Regression and inverse growth model was employed to find out the significant duration between the onset of nevirapine rash and initiation of ART. Mean duration of onset of nevirapine rash was $12.40 \pm 3.78$ days, with mean CD4 count at the time of drug reaction was $162.10 \pm 32.61 \mathrm{microns} / \mathrm{dl}$. It was observed that the correlation co-efficient $(\mathrm{r}=0.981)$ between the onset of nevirapine rash and CD4 count was significant $(\mathrm{P} \leq 0.05)$, which clearly depicts the association of the onset of nevirapine rash to low CD4 count $(<200$ microns/dL).

\footnotetext{
* Correspondence: drleelaskincare@rediffmail.com

Bowring and Lady Curzon Hospital, Bangalore Medical College \& Research Institute, Bangalore, India
}

(c) 2012 Budamakuntla et al; licensee BioMed Central Ltd. This is an Open Access article distributed under the terms of the Creative Commons Attribution License (http://creativecommons.org/licenses/by/2.0), which permits unrestricted use, distribution, and reproduction in any medium, provided the original work is properly cited.

\section{Conclusion}

NVP rash can show polymorphic manifestations, and the majority of them occurs within first 4-6 weeks of initiation of ART and is often associated with low baseline CD4 count.

Published: 4 May 2012

doi:10.1186/1471-2334-12-S1-09 eruptions to nevirapine - a cross sectional study. BMC Infectious Diseases 2012 12(Suppl 1):09.
Cite this article as: Budamakuntla et al: Spectrum of adverse cutaneous
Submit your next manuscript to BioMed Central and take full advantage of:

- Convenient online submission

- Thorough peer review

- No space constraints or color figure charges

- Immediate publication on acceptance

- Inclusion in PubMed, CAS, Scopus and Google Scholar

- Research which is freely available for redistribution

\section{() Biomed Central}

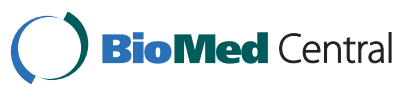

